\title{
Student Satisfaction Towards the Use of F-Learn Services in Online Learning
}

\author{
Sophia Tri Satyawati iD \\ Kristen Satya Wacana University, Salatiga, Jawa Tengah, Indonesia \\ *Corresponding author: sophia.trisatyawati@uksw.edu
}

\begin{abstract}
This research aims to analyse the level of student satisfaction as the users of F-Learn service in online learning. The level of student satisfaction is measured by using the End User Computing Satisfaction (EUCS), model which includes five dimensions, namely: 1) content; 2) accuracy; 3) format; 4) ease of use; and 5) timeliness. The research method used was a survey with a quantitative descriptive approach. The sampling technique used was saturated sampling because the population used in this study was relatively small, namely 30 students as the users of the F-Learn service in online learning. The results show that the level of student satisfaction as users of the F-Learn service in all dimensions are at a good level. Meanwhile, the level of satisfaction in each dimension shows: 1) the content is at an acceptable level; 2) accuracy at the level is quite good; 3) format at an acceptable level, 4) ease of use at an acceptable level; and 5) timeliness at a good enough level. The findings of this study will be used as a measuring tool for the e-learning system (F-Learn) and as input for further development.
\end{abstract}

Keywords: Satisfaction, Content, Accuracy, Format, Ease Of Use, Timeliness

$\begin{array}{lll}\text { History: } & & \text { Publisher: Undiksha Press } \\ \text { Received } & : 2 \text { August } 2020 & \text { Licensed: This work is licensed under } \\ \text { Revised } & : 5 \text { September } 2020 & \\ \text { Accepted } & : 23 \text { September } 2020 & \text { a Creative Commons Attribution 3.0 License } \\ \text { Published } & : 7 \text { October } 2020 & \end{array}$

\section{Introduction}

The development of digital technology in the current Industrial Revolution 4.0 era has brought the changes and influenced various aspects of human life, including in the field of education. Digital technology is the thing that most influences the education system in the world today. is due to the aspects of effectiveness, efficiency, and attractiveness offered by digital technology-based learning. Higher education is time to change learning patterns from conventional to online-based learning by implementing online learning methods for all the courses by utilizing LMS (Learning Management System). Through the LMS, students can access lecture materials, discussion boards through discussion forums, chatroom, and access lecture assignments given by lecturers. Students as users of online learning services must have digital competencies, namely a set of knowledge, skills, attitudes (including abilities, strategies, values, and awareness) needed when using Information and Communication Technology and digital media in learning (Susilahudin, 2018; Kirana, 2018; Suharta, 2017).

Universitas Kristen Satya Wacana Salatiga provides online learning using an ELearning facility known as Flexible Learning (F-Learn). F-Learn is an E-Learning system that used to support learning at the Universitas Kristen Satya Wacana Salatiga. With F-Learn, a Moodle-based LMS (Modular Object-Oriented Dynamic Learning Environment Moodle), which designed to, can facilitate the learning needs of UKSW lecturers and students. F-Learn 
is developed using a Learning Management System (LMS), which can be accessed using a web browser and an application on a smartphone. As the name implies, Flexible Learning (FLearn) is designed to make students more comfortable to learn without being limited by space and time (Kurniawan, 2016).

The application of learning with F-Learn has advantages: In learning preparation, FLearn facilitates teachers in preparing for learning, begins from determining the effective time/week of learning, managing learning to prepare how long learning will take, learning descriptions, learning outcomes, assignments to be given and other learning information. In the implementation of learning, F-Learn is equipped with a student management system and class management, learning can be done without having to meet face to face, allowing teachers and students to add lesson references which are obtained from other sources, teachers can still provide assistance for students who want to ask questions on existing topics of discussion; In learning assessments, teachers can use the features of Moodle F-Learn to prepare the tests, both in the form of multiple-choice, filling, description and even the test can be given a time limit to work on, the teacher can also evaluate the student learning process by looking at the structure of the assignments which are collected, the active students in discussing and / or using F-Learn as a tool of their learning; In learning supervision, teachers can monitor students while having a discussion, access the F-Learn service, even when students access or discuss through F-Learn are appropriately recorded, teachers can also monitor students who have difficulty understanding (Kurniawan, 2016).

However, the field facts show that not a few students complain of experiencing problems and dissatisfaction. Based on the preliminary survey conducted by the researchers, the problems faced by students in using the F-Learn service are: less interesting views per topic; The F-Learn feature is not equipped with video calls to facilitate face-to-face virtual meetings between lecturers and students related to the need for more in-depth study of material and for presentation of student assignments, so lecturers have to combine them with other applications such as zoom or google meet which have been used so far; the maximum file upload limit of $500 \mathrm{~Kb}$ restricts students from uploading larger assignment files; Not all the assignments and test scores are uploaded by the lecturer on the F-learn menu; on the forum menu do not get any response from lecturers; the lecturer has not used maximally the features which are available in F-Learn in learning because more of them are only used to upload learning materials and assignments; and the difficulties in getting an internet connection, especially for students living in rural areas. These problems affect the level of student satisfaction as users of the F-Learn service.

Consumer satisfaction determines by comparing the expected results of a product or service with results based on experience with consuming the product or service. The same result is the satisfaction of consumers, but obtained results are less than expected, it is a form of consumer dissatisfaction (Ludviyatus Sholeha, Sutrisno Djaja, 2018; Machmud, 2018). If the product's performance fills the expectations of consumers, the level of customer satisfaction is high, whereas if the performance of the product cannot fill the consumer expectations, the level of customer satisfaction will low. If the results that are obtained exceed expectations, of course, the user will feel very satisfied (highly satisfied) (Kirana, 2018; Suharta, 2017).

User satisfaction can be fulfilled through product quality and suitability of user perceptions of information systems. Realizing user sufficient is not easy because user satisfaction is difficult to measure and requires special attention. the research results on the level of satisfaction of using the F-Learn service can be used as an effort to upgrade or improve service factors that will help provide added value and bring a right image to the university (Herri \& Zaki, 2017; Machmud, 2018). 
The research conducted by Dedeh (2018), Motilal (2018), and Suciati (2017) shows that students are happy and satisfied using the e-learning Moodle system as a learning tool from anywhere and anytime. They find Moodle very comfortable to use even though they are not very good at the new technology. Likewise, with the research results Kurniasih \& Masduki (2014), and Saifuddin (2018), showing that 77\% of students express satisfaction with the implementation of learning with the e-learning system. Besides, it generates student perceptions that e-learning is useful, can increase motivation, make it easier to understand the material, and help prepare for lectures (Bora, 2017; Santosa, 2020). Students are satisfied with online learning with Moodle as an LMS which is significantly influenced by how learning is organized and how content is sorted, the ease with which students can complete assignments, and the use of LMS to engage with content (Xu \& Mahenthiran, 2016). In general, research results show that students are satisfied with the online learning process that is being followed.

However, it is different from the research results Irawati \& Jonatan (2020), which shows that all 17 attributes measured produce negative gaps. This shows that there is a gap between the perceptions and expectations of students in online learning. The overall value of the 17 attributes gap is negative, meaning that all respondents studied expressed dissatisfaction with online learning services. Likewise, both from the technology and lecturer sides, students are not satisfied with the online distance learning method they are currently doing and are also dissatisfied with the ability of the lecturer to deliver material on distance learning online (Napitupulu, 2020). Online activities carried out are boring, so it hopes that lecturers will be more creative and innovative in utilizing the media used to make the learning process more enjoyable (Aswasulasikin, 2020). Online using a variety of advanced features cannot replace lecturers' role through face-to-face lectures, because it provides more motivation and enthusiasm for students to learn rather than take lectures through an online pattern. The level of student satisfaction at Pasundan University in Bandung using-learning is relatively low because the value of the level of expectation is higher than the level of reality accepted by students (Darmawan, 2015). All the qualities provided by e-learning, both in terms of system quality, information quality, and service quality have not been able to satisfy students due to various factors, including students as users feel uncomfortable in accessing e-learning, lack of accuracy, and there is no urgency if there is an error in use (Niken, 2019).

The gap in previous research results that is relevant to satisfaction with e-learning system services in online learning shows some problems that need to be researched because the success of the implementation of e-learning in universities is strongly influenced by user satisfaction and the perception of using the e-learning system (Rahmat et al., 2019; Sarjono, 2017).

This study aims to analyse students 'level of satisfaction using the F-Learn service in online learning. The level of student satisfaction is measured using the End User Computing Satisfaction (EUCS), model which includes five dimensions: content, accuracy, format, ease of use, and timeliness. Each dimension has indicators that can be known in more detail about the level of student satisfaction so that the results of this study are expected to contribute to improving the quality of F-Learn services in online learning.

\section{Materials and Methods}

This study used a survey method with a qualitative descriptive approach. The research population was 30 students of the 2019 Universitas Kristen Satya Wacana (UKSW) Education Management Masters study program as users of the F-Learn service in online learning, totaling 30 people. The sampling technique used was saturated sampling, because the population used in this research was relatively small, less than 100 people, or research 
that wanted to make generalizations with minimalerrors. Saturated sampling technique was a sampling technique when all population members were used as samples (Sugiyono, 2014). If the population was less than 100 people, the total sample was taken, but if the population was more significant than 100 people, $10-15 \%$ or $20-25 \%$ of the population could be taken (Arikunto, 2012). as many as 31 respondents, the authors took $100 \%$ of the Master of Education Management Study Program's total population, as many as 30 people as respondents.

The research data collected using a closed questionnaire technique containing some written statements submitted to respondents to get responses following the statements and instructions for filling out the questionnaire. Respondents who filled out the questionnaire had an online learning experience that experienced the F-Learn service. The questionnaires were distributed and filled in early July 2020. Researchers made online questionnaires for students using the Google Form facility, distributed to respondents via social media, namely Whatsapp. Respondents' satisfaction with these indicators was measured with a Likert scale of $1-5$.

The questionnaire used to collect research data must fill the validity and reliability requirements to obtain objective and accountable data. The instrument's validity test in this study was carried out on 30 trial respondents using SPSS-2,1. Each item was declared valid if

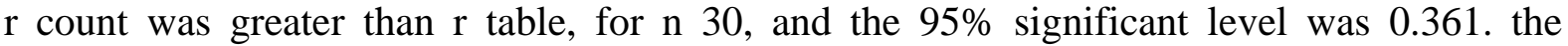
instrument validity test results showed that, there were two invalid instrument items in the content dimension, namely the instrument number 3 and 5, in the timeliness dimension there was 1 item of the instrument that was invalid, namely number 31 . So that the three instruments invalid is eliminated.

the instrument reliability test results were carried out using the Cronbach's Alpha formula assisted by SPSS-21, which showed that all instrument items had high reliability because alpha $>0.700$. The decision-making was based on if the Cronbach Alpha coefficient/value was less than 0.6, then the statement is not reliable (Ghozali, 2018).

Data analysis carried out to determine the level of student satisfaction measured using the End User Computing Satisfaction (EUCS) evaluation model which included five dimensions: content, accuracy, format, ease of use, and timeliness.

\section{Results and Discussion}

The research results for each indicator of the level of student satisfaction with the FLearn service as measured by using the End User Computing Satisfaction (EUCS) model on all dimensions are shown in the following chart in Figure 1.

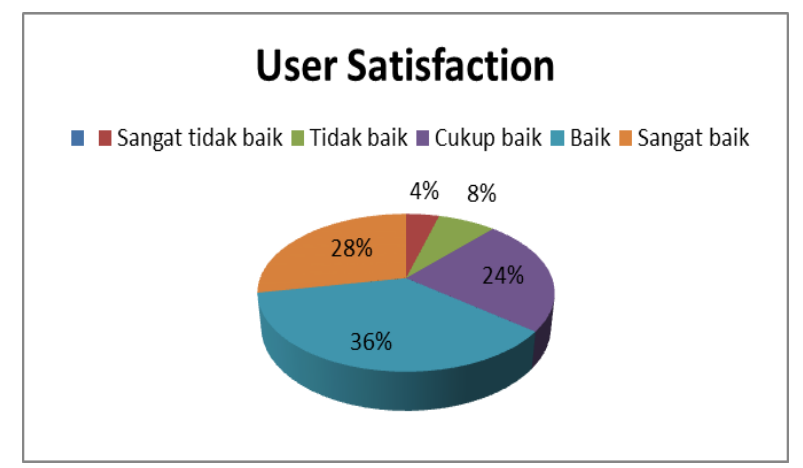

Figure 1. Level of student satisfaction in 5 dimensions

Based on the chart presented in Figure 1, it can be explained that students' perceptions of the F-Learn service in all dimensions, namely dimensions: content, accuracy, format, ease of use, and the highest timeliness of $36 \%$ seen at a good level, $24 \%$ at the same level, and 
$28 \%$ at sufficient level. This means that $88 \%$ of the majority of the 2019 Education Management Master's Program students who use the UKSW F-Learn service have a satisfying response.

In line with the theory of the EUCS evaluation model (Purwandani, 2018), that evaluation using this model emphasizes end-user satisfaction with aspects of technology based on content dimensions, accuracy, format, ease of use of the system, and Its timeliness is proven to measure the use of F-Learning services in the UKSW Management Masters Study Program. By measuring the level of satisfaction using the EUC evaluation model, it supports the theory of Richard L. Oliver (Agussalim M, 2017) that satisfaction is a customer's responsibility for fulfilling their needs. User satisfaction is a subjective criterion regarding how much the user likes the system used. User satisfaction is the response and feedback generated by users after using the information system.

In the context of customers as users of the F-Learn service, including user attitudes towards information systems is a subjective criterion regarding how much users like the system used. User satisfaction is the response and feedback generated by users after using the information system. When the response of students as users of the F-Learn service after using the learning management system in online learning, learning needs are met as expected; it shows user satisfaction.

Likewise, user satisfaction can be defined as a level of user feelings due toa comparison between the user's expectations of a product with the real results obtained from the product (Machmud, 2018). If the product's performance meets the expectations of consumers, the level of customer satisfaction is high, whereas if the performance of the product cannot meet consumer expectations, the level of customer satisfaction will below. If the results that are obtained exceed expectations, of course, the user will feel highly satisfied. The level of consumer satisfaction determines by comparing the expected results of a product or service with the results based on consuming the product or service. The same result is consumers' satisfaction of, but if the results obtained are less than expected, it is a form of consumer dissatisfaction. In the context of students as consumers who use the F-Learn service, they will feel delighted when they feel that their expectations are fulfilled after using the online learning system services.

The research results on the level of student satisfaction with the e-learning system service with the name Moodle-based Flexible Learning (F-Learn) in online learning are supported by Motilal (2018), showing that students are happy and satisfied using Moodlebased E-Learn as a learning tool from anywhere and anytime. They found the Moodle elearning system very comfortable to use even though they are not very good at the new technology. Xu, H., \& Mahenthiran (2016) research shows that overall students are satisfied with online learning with Moodle as an LMS which is significantly influenced by how learning is organized and how content is sorted, the ease of the students can complete assignments, and the use of LMS to engage with content.

Likewise, the research results of Saifuddin (2018) show that $77 \%$ of students express satisfaction with the implementation of learning with e-learning. Besides, it generates students' perceptions that e-learning is useful, can increase motivation, and make it easier to understand the material, and help prepare for lectures. The research results of Suciati (2017) show that in general students are satisfied with the online learning process followed, seen from the relative average score of $83 \%$. This is an indication of the quality of program services as perceived by students.

The results of the research for each indicator of the level of student satisfaction with the F-Learn service as measured by using the End User Computing Satisfaction (EUCS) model on each dimension are as follows: 


\section{Content Dimensions}

the answers to the questionnaire instrument on the content dimensions to measure user satisfaction in terms of the content of the existing system are shown in Figure 2.

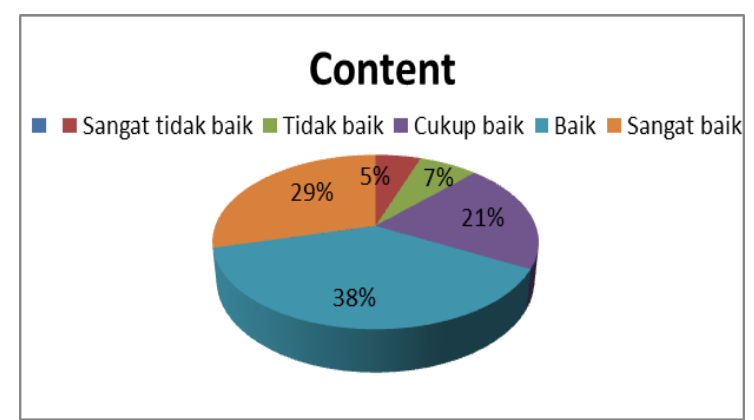

Figure 2. The level of student satisfaction in the Content dimension

Based on the chart presented in Figure 2, it can be explained that students' perceptions of the F-Learn service on the content dimension are the highest at 38\%, seen at the GOOD level and 29\% at the VERY GOOD level, the meaning that the most of the 2019 Education Management Master's Program students as the user of F-Learn UKSW service had a reasonable response satisfaction with F-Learn content.

Student satisfaction with the contents of the system in the form of functions and modules used by system users as well as information generated by the system which explains the respondent's perception of what information is available in a system at an acceptable level includes: Availability of manuals for using F-Learn which make it easier for students to use/operate F-learn; The facilities (features) available in the student room are complete; Attractive graphic display of F-learn; All courses that students take in the face-to-face lecture are available on the F-learn web; All lecture information (materials and assignments and material links) are available on the F-learn web; Attachment files that can be downloaded on the complete F-learn web.

this study supports Schramm's theory that the fulfillment of e-learning is strongly influenced by the quality of learning source content rather than the type of equipment used to provide guidance (Radha et al, 2019). The content quality of the e-learning system includes the words used, explanations, and examples provided for better understanding, the current information, information sequences, content presentation, and meeting user expectations of content. The main objective of each e-learning system is to deliver appropriate content or information according to the users to develop their knowledge in a particular domain so that the quality of content is a significant component of the e-learning system.

\section{Accuracy dimension}

The answers to the questionnaire instrument on the accuracy dimension to measure user satisfaction in terms of data accuracy when the system receives the input and then process it into content information are shown in Figure 3.

Based on the chart presented in Figure 2, it can be explained that students' perceptions of the F-Learn service on the highest accuracy dimension of $43 \%$ are seen at the GOOD ENOUGH level and 21\% at the GOOD level, the meaning that most of the 2019 Education Management Master's Program students as the user of F-Learn UKSW service had a response satisfaction is quite good with F-Learn's accuracy dimension. 


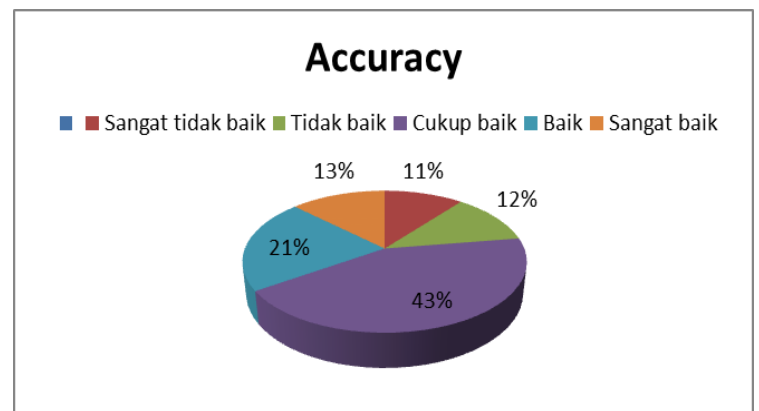

Figure 3. The level of student satisfaction on the accuracy dimension

Student satisfaction in terms of data accuracy when the system accepts input then processes it into this information explains the respondent's perception of the information provided by F-Learn, which must be error-free, in the sense that the error rate must be identified, whether the information is error-free or contains errors elements which include: Information which is presented in the F-learn web according to the syllabus / RPS lectures in face-to-face lectures; Attachment files that can be downloaded on the F-learn web according to the course syllabus / RPS; The results of the assignment scores that are presented in the Flearn web are calculated correctly and following the assignments that have been uploaded by students; The lecturer uploads the value according to the assignment that is given; Lecturer gives the feedback to the forum feature on assignments given to students.

The findings of this study are in line with Yazid \& Wijoyo (2019) states that accuracy is one of the characteristics that affect the level of user satisfaction in accessing information. Accuracy in e-learning applications is a measure of error-free information. Data credibility can be the responsibility of the application manager in delivering information. Errors in the accuracy of data or information presented in a system or application can cause severe problems for end-users.

\section{Format Dimensions}

The answers to the questionnaire instrument on the format dimensions to measure user satisfaction in terms of the appearance of the application program itself are shown in Figure 4.

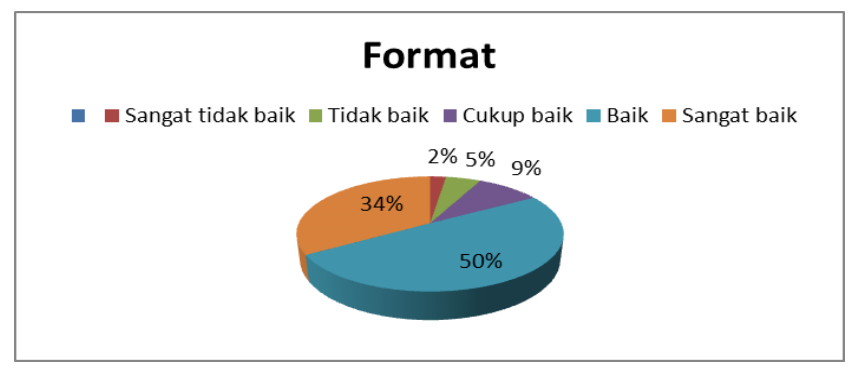

Figure 4. The level of student satisfaction in the format dimensions

Based on the chart presented in Figure 4, it can be explained that student perceptions of the F-Learn service in the highest format dimensions of 50\% are seen at the GOOD level and $34 \%$ at the GOOD level, the meaning that most students of the 2019 Education Management Masters Study Program as the users of the F-Learn UKSW service had a good satisfaction response to the format F-Learn.

Student satisfaction in terms of format measures user satisfaction in terms of the appearance of the application program itself, which explains the respondent's perception of 
the clear form provided by F-learning, such as the layout and navigation which is contained in F-Learn, including the availability of space that provides lecture material; space to access lecture materials; a room that provides assignments, exercises, quizzes, and tests/exams; there is space to access assignments, exercises, quizzes, and tests/exams; space that can be used to send assignments (upload assignments); the space that provides the results of the assignments I have uploaded; a room to chat among fellow F-learning users.

The findings of this study are in line with the opinion in the results of the study Adianto (2018), that the format dimension emphasizes on the appearance of the information system in terms of an orderly layout, colour combinations that meet aesthetic standards, and information systems also have standardization in form uniformity. So that the format or visual appearance of an information system is needed to attract its users' interest

\section{Dimensions of ease of use}

The answers to the questionnaire instrument on the ease of use dimension to measure user satisfaction or user friendly in using a system such as a process of entering data, processing data, and looking for information are shown in Figure 5.

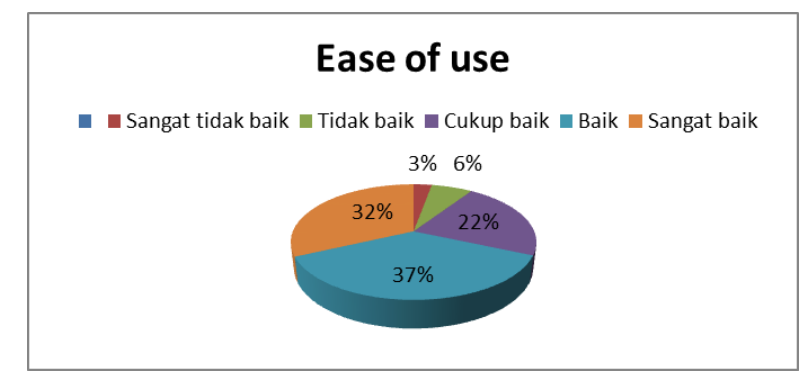

Figure 5. The level of student satisfaction in the dimension of ease in use

Based on the chart presented in Figure 5, it can be explained that student perceptions of the F-Learn service on the highest ease of use dimension of $37 \%$ are seen at the GOOD level and 32\% at the level seen at the VERY GOOD level, the meaning that most of the students 2019 of the Master of Education Management Study Program as the users F-Learn UKSW service has a satisfaction response to the ease of use of F-Learn.

Student satisfaction in terms of ease of use measures user satisfaction or user friendly in using systems such as the process of entering data, processing data, and searching for information, explaining respondents' perceptions that the e-learning system must be easy to use (user-friendly) by users who are using e-learning, including ease of getting guidance on how to use/operate F-learning; the F-learning layout is easy to understand its usefulness; ease of selecting or entering into the desired courses; ease of managing user accounts in F-learning including editing of personal data and posting of photos; ease to login and logout to the Flearning web; the ease of downloading the attachment files for courses on the F-learning web; easy to know the status of the submission of the assignments that I uploaded on the Flearning web; easy to see the value of course assignments in F-learning.

Ease of use of information systems is supported by several criteria such as ease of use of information systems so as not to confuse users, consistent use, availability of supporting tools that facilitate use, and provide more informative error messages to provide error messages that are easily understood by system users information (Kurniadi, 2019; Kurniadi, 2017). 


\section{Timeliness Dimension}

The answers to the questionnaire instrument on the timeliness dimension measure user satisfaction in terms of the timeliness of the system in presenting or providing data and information needed by users, it is shown in Figure 6.

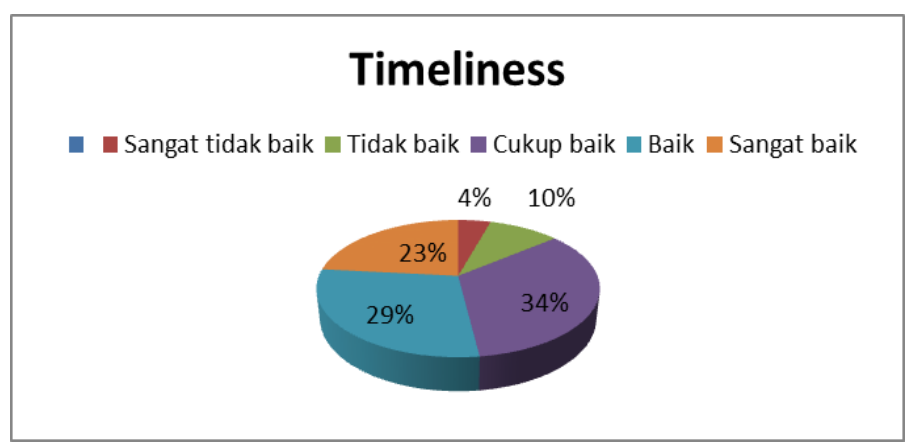

Figure 6. The level of student satisfaction in the dimension of timeliness

Based on the chart presented in Figure 5, it can be explained that students' perceptions of the F-Learn service in the highest timeliness dimension, 34\%, are seen at the GOOD ENOUGH level and 23\% at the VERY GOOD level, the meaning that most of the 2019 Education Management Master's Program students the users of F-Learn UKSW service had a good satisfaction response to the timeliness dimension of the F-Learn service.

Student satisfaction in terms of timeliness, namely measuring user satisfaction in terms of timeliness of the system in presenting or providing data and information needed by users, including the speed of the time when accessing the F-Learn web; the information presented in the F-learning web is always up-to-date; a guide to using F-learning is provided at the beginning of the lecture which is on the front page of the F-learn feature; 4) Syllabus / RPS information is presented on the F-learn website at the beginning of the lecture; course material is presented in the F-learn web according to the lecture schedule; assignments are presented in the F-learn web according to the lecture schedule; the deadline for submitting assignments through F-learn is following the limits at the time of the lecture, and the assessment is presented in the F-learn web on time.

The findings of this study support the results of research (Adianto, 2018), that the timeliness of LSM can be seen from the fast response time and according to the needs of users, the information available in the information system is up-to-date, and the availability of shortcuts in carrying out the process of fast work.

Based on the research findings described above, the results of this study support the theory of the EUCS evaluation model which is developed (Purwandani, 2018), that evaluation by using this model emphasizes on the end-user satisfaction with aspects of technology based on content dimensions, accuracy, format, ease of use of the system, and timeliness are proven to measure the use of F-Learning services in the Management Masters Study Program UKSW. By measuring the satisfaction level using the EUC evaluation model, it supports the theory Sastradiharja (2019) that satisfaction is a customer's response to meeting their needs. User satisfaction is a subjective criterion regarding how much the user likes the system used. User satisfaction is the response and feedback generated by users after using the information system.

\section{Conclusion}

Based on the research results described above, this study's conclusions are: The overall satisfaction level of F-Learn UKSW students in online learning is at a good level. Meanwhile, the satisfaction level in each dimension shows: The content dimension shows 
that the satisfaction level of F-Learn UKSW students in learning is at a good level; On the accuracy dimension, it shows that the level of satisfaction of F-Learn UKSW students in learning is at a reasonable good level; The format dimension shows that the level of satisfaction of F-Learn UKSW students in learning is at a good level; In the ease of use dimension, it shows the level of satisfaction of F-Learn UKSW students in learning at a good level; and On the timeliness dimension, it shows that the level of satisfaction of F-Learn UKSW students in learning is at a reasonably good level.

\section{References}

ABD Rahmat, Kudang Boro Seminar, \& A. I. S. (2019). Evaluasi Keberhasilan E-Learning Dalam Perspektif Sistem Informasi (Studi Kasus Universitas Terbuka). Jurnal Aplikasi Manajemen, 5(3), 373-384. https://doi.org/10.17358/jabm.5.3.373

Adianto, D. R. (2018). Analisis Kepuasan Penerimaan Pengguna Akhir Sistem Branch Delivery System (Bds) Pada Layanan Teller Cash Recycler (Tcr) Menggunakan End User Computing Satisfaction (Eucs) Dan Iso/Iec 12207:2008 Pada Perusahaan Bank Di Indonesia. Jurnal Sistem Informasi Indonesia, 3(1), 1-14.

Agussalim M, \& H. A. (2017). Model Kepuasan Pelanggan: Analisis Kualitatif Produk dan Kualitas Layanan terhadap Citra Merk pada Giant Citra Raya Jakarta. Jurnal Manajemen, 21(3), 317-335. http://dx.doi.org/10.24912/jm.v21i3.254

Arikunto, S. (2012). Prosedur Penelitian Suatu Tindakan Praktek. Rineka Cipta.

Aswasulasikin, A. (2020). Persepsi Mahasiswa Terhadap Kuliah Daring di masa Pandemi Corona Virus Disease (COVID-19). SALAM: Jurnal Sosial Dan Budaya Syar-I, 7(8), 100-108.

https://www.researchgate.net/deref/http\%3A\%2F\%2Fdx.doi.org\%2F10.15408\%2Fsjsbs. $\underline{\mathrm{v} 7 \mathrm{i} 8.15734}$

Bora, I. S. B. \& M. A. (2017). Analisa Kepuasan Penggunaan E-Learning Cloud Sekolah Tinggi Teknik (STT). Jurnal Kreatif Industri (JIK), 1(1), 22-62. https://doi.org/10.36352/jik.v1i01.49

Darmawan, F. (2015). Pengukuran Tingkat Kepuasan Pemanfaatan E-Learning (Studi Kasus: E-Learning IF UNPAS). Journal Speed, 7(4), 343-347. http://speed.web.id/ejournal/index.php/speed/article/view/135/130

Dedeh. (2018). Analisis Tingkat Kepuasan Mahasiswa terhadap Layanan Akademik Program Studi Pendidikan Akuntansi FKIP Universitas Galuh. Jurnal Wahana Pendidikan, 5(1), 1-20. http://dx.doi.org/10.25157/wa.v5i1.929

EE Junaedi Sastradiharja, W. D. S. (2019). Pengaruh Persepsi Faktor Rasional dan Emosional terhadap Kepuasan Orang Tua Siswa di Sekolah Dasar Islam Terpadu Lentera Ilmu Kota Tangerang. Andragogi: Jurnal Pendidikan Islam, 1(1), 103-129. https://www.researchgate.net/deref/http\%3A\%2F\%2Fdx.doi.org\%2F10.36671\%2Fandra gogi.v1i1.50

Ghozali, I. (2018). Aplikasi Analisis Multivariete dengan Program IBM SPSS 25. Badan Penerbit Universitas Diponegoro.

Herri Affandi, Muhammad Zaki, \& A. (2017). Pengaruh Kualitas Layanan Terhadap Kepuasan pelanggan Pada Perusahaan Daerah Air Minum (PDAM) Tirta Mon Pase Kabupaten Aceh Utara. Jurnal Teknik Sipil, 6(3), 297-308. http://jurnal.unsyiah.ac.id/JTS/article/view/9845 
Irawati, D. Y., \& Jonatan, J. (2020). Evaluasi Kualitas Pembelajaran Online Selama Pandemi Covid-19: Studi Kasus di Fakultas Teknik, Universitas Katolik Darma Cendika. Jurnal Rekayasa Sistem Industri, 9(2), 135-144. https://doi.org/10.26593/jrsi.v9i2.4014.135$\underline{144}$

Kirana Rukmayuninda Ririh, F. M. P. (2018). Pengembangan Model Kualitas Pelayanan Jasa Pendidikan Sekolah Karakter di Jakarta. Jurnal Optimasi Sistem Industri, 17(2), 188197. https://doi.org/10.25077/josi.v17.n2.p188-197.2018

Kurniadi, A. S. \& D. (2019). Analisis Kepuasan Pengguna Sistem Informasi E-Campus di IAIN Bukittinggi Menggunakan EUCS. Jurnal Resti (Rekayasa Sistem Dan Teknologi Informasi, $3(1)$, 23-28. http://ejournal.unp.ac.id/index.php/voteknika/article/view/105157

Kurniadi, K. A. Z. \& D. (2017). Analisa Kepuasan Pengguna Aplikasi E-XAMP Editor Sebagai Aplikasi Ujian Sekolah Berbasis Computer Di SMKN 3 Pariaman Menggunakan Metode EUCS Yang Diperluas. Jurnal Vokasional Teknik Elektronika Dan Informatika, 5(2), 83-88. http://ejournal.unp.ac.id/index.php/voteknika/article/view/8490

Kurniasih, Em. Masduki, L. R. (2014). Tingkat Kepuasan Mahasiswa Terhadap Layanan Online Mata Kuliah Kurikuler Matematika. Jurnal Aksioma, 5(1), 1-16. https://doi.org/10.26877/aks.v5i1/MARET.560

Ludviyatus Sholeha, Sutrisno Djaja, \& J. W. (2018). Pengaruh Kualitas layanan Terhadap Kepuasan Pelanggan di AHASS Sumber Jaya Maha Sakti Kecamatan Rogojampi Kabupaten Banyuwangi. Jurnal Pendidikan Ekonomi, 12(1), 15-25. https://doi.org/10.19184/jpe.v12i1.6465

Machmud, R. (2018). Study of Satisfaction of Information System Users in Study Program (SIMPRODI) in Gorontalo State University. International Journal of Applied Business and International Management, 3(2), 57-70. https://doi.org/10.32535/ijabim.v3i2.339

Motilal, M. (2018). Level of Satisfaction using Moodle as an E-Learning Tool for Students in B-School. Global Journal of Computer Science and Technology, 18(1), 10-22. https://www.slideshare.net/RittikaMotilal/level-of-satisfaction-using-moodle-as-aelearning-tool

Muhammad Ainu Yazid, Satrio Hadi Wijoyo, \& R. I. R. (2019). Evaluasi Kualitas Aplikasi Ruang Guru terhadap Kepuasan Pengguna menggunakan metode EUCS (End User Computing Satisfaction) dan IPA (Importance Performance Analysis). Jurnal Pengembangan Teknonoli Informasi Dan Ilmu Komputer, 3(9), 1-16. http://jptiik.ub.ac.id/index.php/j-ptiik/article/view/6189

Napitupulu, R. M. (2020). Dampak pandemi Covid-19 terhadap kepuasan pembelajaran jarak jauh. Jurnal Inovasi Teknologi Pendidikan, 7(1), 23-33. https://doi.org/10.21831/jitp.v7i1.32771

Niken Ayu Larasati, \& S. A. (2019). Pengaruh Penggunaan Learning Management System (LMS) Terhadap Tingkat Kepuasan Mahasiswa Menggunakan Metode DeLone and McLean. Jurnal Teknik Informatika Unika St. Thomas (JTIUST), 4(1), 13-20. http://dx.doi.org/10.17605/jti.v4i1.506

Purwandani, I. (2018). Analisa Tingkat Kepuasan Pengguna Elearning Menggunakan EUCS dan Model Delone and McLean. Indonesian Journal on Software Engineering, 4(2). https://doi.org/10.31294/ijse.v4i2.5989 
Radha, S., Michael Mariadhas, J., Subramani, A.K., and Akbar Jan, N. (2019). Role of elearning and digital media resources in employability of management students. The Online Journal of Distance Education and E-Learning, 7(2), 116-123. https://tojdel.net/journals/tojdel/articles/v07i02/v07i02-06.pdf

Saifuddin, M. F. (2018). E-learning dalam persepsi mahasiswa. Jurnal Varidika, 29(2), 102109.

https://www.researchgate.net/deref/http\%3A\%2F\%2Fdx.doi.org\%2F10.23917\%2Fvarid ika.v29i2.5637

Santosa Wijayanto, \& G. N. P. (2020). Pengukuran Tingkat Kepuasan Pemanfaatan Google Classroom sebagai Media Pembelajarandi SMK Negeri 2 Tangerang Selatan. Jurnal Ilmu Komputer (JIK), 3(3), 23-27. pranataindonesia.ac.id/index.php/jik/article/view/37

Sarjono, H. (2017). Analisis Pengaruh Kepuasan Mahasiswa terhadap Proses pembelajaran Secara E-Learning. Business Management Journal, 4(1), 1-18. http://dx.doi.org/10.30813/bmj.v4i1.647

Suciati, S. (2017). Interaksi Kesiapan Belajar Dan Kepuasan Terhadap Layanan Pada Pembelajaran Online Program Pascasarjana. Cakrawala Pendidikan, 1, 70-80. https://doi.org/10.21831/cp.v36i1.12733

Sugiyono. (2014). Metode Penelitian Pendidikan Pendekatan Kuantitatif, Kualitatif, dan $R \& D$. Alfabeta.

Suharta, T. (2017). Pengembangan Instrumen Pengukur Tingkat Kepuasan Siswa Terhadap Kualitas Layanan Pendidikan di Sekolah. Jurnal Evaluasi Pendidikan, 8(2), 117-125. https://doi.org//10.21009/JEP.082.07

Susilahudin Putrawangsa, \& U. H. (2018). Integrasi Teknologi Digital Dalam Pembelajaran di Era Industri 4.0: Kajian dari Perspektif Pembelajaran Matematika. Jurnal Penelitian Dan Pemikiran Pendidikan (TATSQIF), 16(1), 1-17. https://doi.org/10.20414/jtq.v16i1.203

$\mathrm{Xu}$, H., \& Mahenthiran, S. (2016). Factors that influence online learning assessment and satisfaction: Using Moodle as a Learning Management System. International Business Research, $9(2)$, $1-18$. https://www.researchgate.net/deref/http\%3A\%2F\%2Fdx.doi.org\%2F10.5539\%2Fibr.v9 $\underline{\mathrm{n} 2 \mathrm{p} 1}$ 